\title{
BUTORPHANOL AS AN ADJUVANT TO LEVOBUPIVACAINE IN SUPRACLAVICULAR BRACHIAL PLEXUS BLOCK FOR UPPER LIMB ORTHOPAEDIC SURGERIES: A RANDOMIZED, DOUBLE BLIND, PLACEBO- CONTROLLED STUDY
}

\author{
Basavaraj Bommalingappaㄹ, Shivakumar M. Channabasappa²
}

${ }^{1}$ Associate Professor, Department of Anaesthesiology, Subbaiah Institute of Medical Sciences and Research Centre. 2Professor, Department of Anaesthesiology, Subbaiah Institute of Medical Sciences and Research Centre.

ABSTRACT
OBJECTIVE
To compare the duration of sensory blockade of butorphanol-levobupivacaine mixture with levobupivacaine in supraclavicular
brachial plexus block for upper limb orthopaedic surgeries.

\section{SETTING AND DESIGN}

Prospective randomized double-blind case control comparative study conducted at tertiary level teaching hospital.

\section{MATERIALS AND METHODS}

50 patients aged between 20-70 yrs. of ASA grade 1 and 2 undergoing elective upper limb orthopaedic surgeries were randomly allocated into two groups of 25 patients each. Patient in Group A and Group B. In Group A ( $\mathrm{n}=25), 24 \mathrm{~mL}$ of $0.5 \%$ levobupivacaine $+1 \mathrm{~mL}(1 \mathrm{mg})$ Butorphanol; and in Group B ( $=25), 24 \mathrm{~mL}$ of $0.5 \%$ levobupivacaine $+1 \mathrm{~mL}$ normal saline were given for supraclavicular brachial plexus block using the peripheral nerve stimulator. Onset and duration of sensory and motor blocks were assessed along with the duration of analgesia, sedation and adverse effects if any. Haemodynamic parameters like Heart Rate (HR), Systolic Arterial Blood Pressure (SBP) and Diastolic Arterial Blood Pressure (DBP) were also monitored.

\section{RESULTS}

Demographic data and surgical characteristics were comparable in both the groups. The onset times for sensory and motor blocks were significantly shorter in A than B Group $(\mathrm{P}<0.001)$, while the duration of blocks was significantly longer $(\mathrm{P}<0.001)$ in A Group. Significantly, onset of action was rapid in Group A patients compared to Group B patients, a higher number of patients in Group B requested for rescue analgesia during the post-operative period than in Group A. The average time duration of surgery in Group A is $79.8 \pm 12$ minutes and $72.72 \pm 11$ minutes in Group B. The average time for first request for rescue analgesia were 279.16 mins. and 218.64 mins. in Group A and B respectively.

\section{CONCLUSION}

Butorphanol added as an adjuvant to levobupivacaine for supraclavicular brachial plexus block significantly shortens the onset time and prolongs the duration of sensory and motor blocks and duration of analgesia. Patients in Group A were adequately sedated (Modified Ramsay Sedation Score, RSS $=2 / 6$ or $3 / 6$ ) with no adverse effects.

\section{KEYWORDS}

Analgesia, Levobupivacaine, Butorphanol, Supraclavicular Brachial Plexus Block.

HOW TO CITE THIS ARTICLE: Bommalingappa B, Channabasappa SM. Butorphanol as an adjuvant to levobupivacaine in supraclavicular brachial plexus block for upper limb orthopaedic surgeries: a randomized, double blind, placebo controlled study. J. Evolution Med. Dent. Sci. 2016;5(60):4194-4197, DOI: 10.14260/jemds/2016/957

\section{INTRODUCTION}

Butorphanol is a synthetically derived opioid agonistantagonist analgesic of the phenanthrene series. It exhibits partial agonist and antagonist activity at the $\mu$ opioid receptor and agonist activity at the $\mu$ receptor. Stimulation of these receptors on central nervous system neurons causes an intracellular inhibition of adenyl cyclase, closing of influx membrane calcium channels and opening of membrane potassium channels.

Financial or Other, Competing Interest: None.

Submission 21-06-2016, Peer Review 16-07-2016,

Acceptance 22-07-2016, Published 27-07-2016.

Corresponding Author:

Dr. Basavaraj Bommalingappa,

Matrushree,

Vinayaka Nagar,

Near Rotary Blood Bank,

Shimoga-577201.

E-mail: bassi69@rediffmail.com

DOI: $10.14260 /$ jemds $/ 2016 / 957$
This leads to hyperpolarisation of the cell membrane potential and suppression of action potential transmission of ascending pain pathways. ${ }^{[1]}$

It will always be the interest of an anaesthetist to increase the quality of local anaesthetics and to prolong the duration of surgical anaesthesia and analgesia. Previously different studies used as adjuvant to local anaesthetics to prolong the block and reduce the toxicity. For example, for axillary brachial plexus blockade different additives like tramadol.[2], dexamethasone. ${ }^{[3]}$ and clonidine. ${ }^{[4]}$ have been added to local anaesthetics like mepivacaine and lignocaine. Butorphanol has been used alone and in combination with a local anaesthetic like mepivacaine.[5] for brachial plexus blockade. The aim of this placebo controlled study was to evaluate the effect of butorphanol versus placebo as adjuvant to levobupivacaine for supraclavicular brachial plexus blockade on the onset and duration of blockade, duration of analgesia for orthopaedic surgeries of upper limb. 


\section{MATERIALS AND METHODS}

This prospective, randomized double-blind study was conducted after approval of Institutional Ethical Committee and informed and written consent of patients; 50 patients aged between 20-70 years belonging to ASA grade 1 and 2 scheduled for upper limb orthopaedic surgeries randomized into 2 groups by computerized randomisation technique. Patients in Group A received $1 \mathrm{~mL}(1 \mathrm{mg})$ butorphanol +24 $\mathrm{mL}$ of $0.5 \%$ of levobupivacaine total of $25 \mathrm{~mL}$ mixture and patients in Group B received $1 \mathrm{~mL}$ normal saline $+24 \mathrm{~mL}$ $0.5 \%$ bupivacaine total of $25 \mathrm{~mL}$ for supraclavicular brachial plexus block. All patients underwent general physical examination and systemic examination was explained the Linear Visual Analogue Scale [LVAS].[6] for scoring system of pain during the Pre-Anaesthetic Examination (PAE). The LVAS used a $10 \mathrm{~cm}$ scale, where 0 denotes no pain, while 10 denotes worst pain.

\section{Statistical Analysis}

Data are summarized as mean \pm standard deviation or as percentages. Statistical analysis was performed by GraphPad Prism version 4 [GraphPad Software Inc.; San Diego, California, USA; 2005] software. Comparison of categorical variables between the two groups was by Chi-square test or Fisher's exact test as appropriate. Numerical variables were normally distributed and were compared by Student's unpaired ' $\mathrm{t}$ ' test. All analyses were two-tailed and $\mathrm{P}<0.05$ was considered statistically significant.

Visual Analogue Scale (VAS).

012345678910

\section{Exclusion Criteria}

1. Allergic to local anaesthetics.

2. Neurological disorders.

3. Skin infection at the site of procedure.

4. Coagulation disorders.

5. Uncooperative patients.

6. Patient refusal.

7. Severe chronic obstructive pulmonary disease.

Patients kept fasting for $6 \mathrm{hrs}$. to solids and $2 \mathrm{hrs}$. for clear liquids. In the Operation theatre, IV line was established. The anaesthesia mixture were prepared by a trained anaesthesia technician beforehand to maintain the blinding process. Baseline HR, SBP, DBP, RR, SPO2 was recorded. Supraclavicular brachial plexus nerve block was performed with the aid of a peripheral nerve stimulator by using 22-G short bevelled, insulated $55 \mathrm{~mm}$ long-stimulating needle. Stimulation frequency was set at $2 \mathrm{~Hz}$, while intensity of stimulating current was initially set to deliver $1 \mathrm{~mA}$, gradually decreased to $0.6 \mathrm{~mA}$. Negative aspiration was performed while injecting the drug solution to avoid any intravascular placement. Sensory and motor blocks on the operated limb were evaluated after the completion of anaesthetic injection by one of the investigator who was unaware of drug combination administered.

Monitoring such as pulse oximetry, electrocardiography and non-invasive arterial blood pressure monitoring was done regularly by the anaesthesiologists. Time required achieving surgical block in the operation theatre and the time to rescue analgesic in the post anaesthesia care unit were also recorded. Parameters observed were tabulated and analysed.

Intraoperatively Heart rate, Respiratory rate, SPO2 were recorded at every 3 mins. interval for first 20 mins. and thereafter every 15 mins. till the completion of surgery. Sensory block was assessed; pin prick test and motor block was assessed by modified Bromage scale.[7] The assessment was started 5 mins. after the procedure performed till complete sensory and motor block achieved. Time taken for complete sensory and motor block were recorded. Side effects such as vomiting, shivering, bradycardia, desaturation were recorded. Parameters observed day patients were asked regularly for persistence of tingling or numbness sensation. Thereafter,

- Onset time of sensory block.

- Onset time of motor block.

- Duration of motor block.

- Duration of post-operative analgesia.

- Any suspected adverse effect.

\section{Sensory Block was Assessed by Pin Prick Method}

- Grade 0: Sharp pain,

- Grade 1: Touch sensation,

- Grade 2: No sensation (Anaesthesia).

Sensory Score at 2 was taken as the time of onset of Sensory Block. Motor Block Assessed by Bromage Scale as,

- 0: Normal motor function,

- 1: Decreased motor strength with ability to move the fingers only,

- 2: Complete motor block with inability to move the fingers.

Recovery of sensory block was assessed 120 mins. after the onset of action. Thereafter, recovery was assessed every 30 mins. till complete recovery achieved and time were recorded. Patients reporting a LVAS score of $\geq 4$ requesting for rescue analgesia was achieved with intravenous infusion of $1 \mathrm{gm}$ paracetamol $8^{\text {th }}$ hrly. From $2^{\text {nd }}$ post-operative patients were followed up daily till their discharge.

\section{RESULTS}

There were 25 patients in each group; there was no statistically significant difference between Group A and Group B with respect to age, gender, weight and duration of surgery.

There was significant faster onset of both sensory and motor analgesia in butorphanol group in comparison to control group, which was statistically significant $(\mathrm{p}<0.001)$. The mean time from block placement to first request for analgesia (The duration of analgesia) was $279.16 \pm 12.1$ mins. in the butorphanol treated group, but $218.64 \pm 11.4$ mins. in the control group which was significant ( $p<0.001$ ) (Table 2).

At 180 mins. butorphanol group had significantly lower VAS score as compared to control group. At 240 mins. all the patients in control group had VAS score $>4$ and received rescue analgesia. Patients receiving butorphanol had lower LVAS pain score compared to control group. Control group patients requested rescue analgesia earlier than patients in butorphanol group in post-operative period. The average 
time for first request rescue analgesia were 279.16 mins. and 218.64 mins. in Group A and Group B respectively.

No patient had respiratory depression in either groups (Respiratory rate $<8)$, desaturation $\left(\mathrm{SpO}_{2}<90\right)$, no nausea or vomiting, intraoperative shivering (Table 4); 7 patients in butorphanol group had Ramsay sedation score of 4 and 5 patients had RSS of between 3, 13 patients had RSS of 2 .

No patients had RSS of more than 4; 6 patients in control group had RSS score of 1 and they received rescue sedation with $1 \mathrm{mg}$ midazolam IV; 19 patients in control group had RSS score of 2 (Table 5).

\begin{tabular}{|c|c|c|c|}
\hline Parameter & Group A & Group B & P value \\
\hline Age [yrs.] & 39.36 & 39.4 & NS \\
\hline $\begin{array}{c}\text { Gender (m:f) } \\
(\%)\end{array}$ & $\begin{array}{c}14: 11 \\
(56 \%: 44 \%)\end{array}$ & $\begin{array}{c}17: 08 \\
(68 \%: 32 \%)\end{array}$ & NS \\
\hline Weight (kg) & 62.64 & 64.16 & NS \\
\hline $\begin{array}{c}\text { Duration of } \\
\text { Surgery (mins.) }\end{array}$ & 79.8 & 72.72 & NS \\
\hline Table 1: Demographic Data and Duration of Surgery in \\
Two Groups (Mean \pm SD) \\
\hline
\end{tabular}

\begin{tabular}{|c|c|c|c|}
\hline Parameter & Group A & Group B & P value \\
\hline $\begin{array}{c}\text { Onset of sensory } \\
\text { block }\end{array}$ & $12.3 \pm 2$ & $16.4 \pm 3.2$ & $\mathrm{P}<0.005$ \\
\hline $\begin{array}{c}\text { Onset of motor } \\
\text { block }\end{array}$ & $10.1 \pm 2.1$ & $12.3 \pm 2.8$ & $\mathrm{NS}$ \\
\hline $\begin{array}{c}\text { Duration of } \\
\text { analgesia }\end{array}$ & $279.16 \pm 12.6$ & $218.64 \pm 8.6$ & $\mathrm{P}<0.005$ \\
\hline $\begin{array}{c}\text { Duration of } \\
\text { motor block }\end{array}$ & $256.6 \pm 14.6$ & $168.8 \pm 11.4$ & $\mathrm{P}<0.005$ \\
\hline
\end{tabular}

Table 2: Duration of Sensory, Motor Block and PostOperative Analgesia (Mean \pm SEM)

\begin{tabular}{|c|c|c|c|}
\hline Time in Mins. & Group A & Group B & P value \\
\hline 120 & 0 & 0 & $\mathrm{NS}$ \\
\hline 150 & 1.1 & 2.2 & $\mathrm{P}<0.005$ \\
\hline 180 & 3.2 & 5.6 & $\mathrm{P}<0.005$ \\
\hline 240 & 5.2 & 17.2 & $\mathrm{P}<0.001$ \\
\hline 300 & 8.1 & 0 & $\mathrm{P}<0.001$ \\
\hline 360 & 6 & 0 & $\mathrm{P}<0.001$ \\
\hline 400 & 1.4 & 0 & $\mathrm{P}<0.005$ \\
\hline Table 3: Number of Patients with VAS $\geq \mathbf{4}$ at and after 120 \\
Minutes from the Onset of Sensory Block \\
\hline
\end{tabular}

\begin{tabular}{|c|c|c|c|}
\hline Parameter & $\begin{array}{c}\text { Group } \\
\text { A }\end{array}$ & $\begin{array}{c}\text { Group } \\
\text { B }\end{array}$ & $\begin{array}{c}\text { P } \\
\text { value }\end{array}$ \\
\hline Bradycardia & $3(12 \%)$ & 0 & NS \\
\hline Vomiting & 0 & 0 & NS \\
\hline $\begin{array}{c}\text { Respiratory depression } \\
(\mathrm{RR}<8)\end{array}$ & 0 & 0 & NS \\
\hline Desaturation $\left(\mathrm{SpO}_{2}<90\right)$ & 0 & 0 & NS \\
\hline Shivering & 0 & 0 & NS \\
\hline \multicolumn{4}{|l}{ Table 4: Adverse Events among Two Groups } \\
\hline
\end{tabular}

\begin{tabular}{|l|c|c|}
\hline \multicolumn{1}{|c|}{ Ramsay Sedation Scale } & $\begin{array}{c}\text { Group } \\
\text { A }\end{array}$ & $\begin{array}{c}\text { Group } \\
\text { B }\end{array}$ \\
\hline $\begin{array}{l}\text { Ramsay 1 } \\
\text { Anxious, agitated, restless }\end{array}$ & 0 & 6 \\
\hline $\begin{array}{l}\text { Ramsay 2 } \\
\text { Cooperative, oriented, tranquil }\end{array}$ & 13 & 19 \\
\hline $\begin{array}{l}\text { Ramsay 3 } \\
\text { Responsive to commands only }\end{array}$ & 5 & 0 \\
\hline
\end{tabular}

\begin{tabular}{|l|c|c|}
\hline $\begin{array}{l}\text { Ramsay 4 } \\
\text { Brisk response to light glabellar tap or } \\
\text { loud auditory stimulus }\end{array}$ & 7 & 0 \\
\hline $\begin{array}{l}\text { Ramsay 5 } \\
\text { Sluggish response to light glabellar tap } \\
\text { or loud auditory stimulus }\end{array}$ & 0 & 0 \\
\hline \multicolumn{1}{|c|}{ Table 5: Ramsay Sedation Score in Either Group } \\
\hline
\end{tabular}

\section{DISCUSSION}

Use of adjuvant drugs enhances the analgesic efficacy, while reducing the incidence of adverse reactions related to local anaesthetics. Tramadol and fentanyl were used as adjuvant to local anaesthetics in brachial plexus block. ${ }^{[8,9]}$ It was seen that adrenergic receptor agonists improve the nerve block by LA either due to vasoconstriction.[10] or facilitation $C$ fiber blockade.[11] Use of opioids in conjunction with local anaesthetics for supraclavicular brachial plexus block has been associated with decreased pain scores and decreased analgesic requirements in the post-operative period.

The result of this study shows that addition of $1 \mathrm{mg}$ butorphanol to $0.5 \%$ levobupivacaine for supraclavicular brachial plexus blockade results in significant increase in the duration of sensory and motor block compared to control group. Average time for first request of rescue analgesia in our study was about 279.16 mins. in butorphanol group as compared to 218.64 mins. in control group, which was statistically significant $(\mathrm{p}<0.001)$. Results of this study were in concordance with experimental evidence of synergistic interaction between opioids and local anaesthetics. This synergism is due to drug's separate mechanism of action. Blockade of $\mathrm{Na}+$ channels by local anaesthetics and voltage gated $\mathrm{Ca}++$ channels by opioids.[12] Wajima et al showed that continuous infusion of butorphanol locally into the brachial plexus sheath provides superior analgesia to that of continuous IV systemic injection.[13] In another study, Wajima et al found that butorphanol $2 \mathrm{mg}$ with $0.5 \%$ mepivacaine provides sufficient postoperative analgesia after upper limb surgery. ${ }^{[14]}$ The addition of opioids to local anaesthetics allows for a reduction in doses of local anaesthetics, thus decrease in likelihood of side effects. Although 6 patients of butorphanol group had sedation, none of them had respiratory depression. Sedation is a reported side effect of butorphanol when administered neuraxial. Three patients in Group A had bradycardia [HR $<60 /$ mins.], which did not require any treatment.

\section{CONCLUSION}

In this study, we found that butorphanol prolongs the duration of supraclavicular brachial plexus blockade when given along with levobupivacaine. From our study, it is concluded that addition of butorphanol $1 \mathrm{mg}$ to levobupivacaine in supraclavicular brachial plexus block increases the duration of blockade and postoperative analgesia without compromising the haemodynamic parameters.

\section{REFERENCES}

1. Gear RW, Miaskowski C, Gordon NC, et al. The kappa opioid nalbuphine produces gender and dose dependent analgesia and antianalgesia in patients with postoperative pain. Pain 1999;83(2):339-45. 
2. Kapral S, Gollmann G, Waltl B, et al. Tramadol added to mepivacaine prolongs the duration of an axillary brachial plexus blockade. Anesth Analg 1999;88(4):853-6.

3. Movafegh A, Razazian M, Hajimaohamadi F, et al. Dexamethasone added to lidocaine prolongs axillary brachial plexus block. Anesth Analg 2006;102(1):263-7.

4. Iohom G, Machmachi A, Diarra DP, et al. The effects of clonidine added to mepivacaine for paronychia surgery under axillary brachial plexus blockade. Anesth Analg 2005;100(4):1179-83.

5. Wajima Z, Shitara T, Nakajima Y, et al. Continuous brachial plexus infusion of butorphanol-mepivacaine mixtures for analgesia after upper extremity surgery. BJA 1997;78(1):83-5.

6. Carlsson AM. Assessment of chronic pain. I. Aspects of the reliability and validity of the visual analogue scale. Pain 1983;16(1):87-101.

7. Breen TW, Shapiro T, Glass B, et al. Epidural anesthesia for labor in an ambulatory patient. Anesth Analg 1993;77(5):919-24.

8. Kaabachi O, Ouezini R, Koubaa W, et al. Tramadol as an adjuvant to lidocaine for axillary brachial plexus block. Anesth Analg 2009;108(1):367-70.
9. Gaumann DM, Brunet PC, Jirounek P. Clonidine enhances the effects of lidocaine on C-fiber action potential. Anesth Analg 1992;74(5):719-25.

10. Karakaya D, Büyükgöz F, Bariş $S$, et al. Addition of fentanyl to bupivacaine prolongs anesthesia and analgesia in axillary brachial plexus block. Reg Anesth Pain Med 2001;26(5):434-8.

11. Gaumann D, Forster A, Griessen M, et al. Comparison between clonidine and epinephrine admixture to lidocaine in brachial plexus block. Anesth Analg 1992;75(1):69-74.

12. Maves TJ, Gebhart GF. Antinociceptive synergy between intrathecal morphine and lidocaine during visceral and somatic nociception in the rat. Anesthesiology 1992;76(1):91-9.

13. Wajima Z, Nakajima Y, Kim C, et al. I.V. compared with brachial plexus infusion of butorphanol for postoperative analgesia. BJA 1995;74(4):392-5.

14. Bartram DH, Diamond MJ, Tute AS, et al. Use of medetomidine and butorphanol for sedation in dogs. J Small Anim Pract 1994;35(10):495-8. 